\title{
Disciplinary Matchmaking
}

\section{Critics of International Criminal Law Meet Critics of Liberal Peacebuilding}

\author{
Padraig McAuliffe and Christine Schwöbel-Patel*
}

\begin{abstract}
International criminal law is experiencing what has been termed as a 'critical turn'. With several states declaring their intentions to withdraw from the International Criminal Court's constituting treaty in 2016, it seems that critique has never been more timely or necessary. The body of work roughly grouped under an approach referred to as critical approaches to international criminal law has contributed to the debate by foregrounding a structural critique instead of an effectiveness critique (which asks how international criminal law can be improved). We propose that the structural critique may be further developed through an engagement with liberal peacekeeping critique. This body of work, which is critical of liberal peacebuilding practices, has many overlapping points of departure with ongoing work in critical approaches to international criminal law, including its focus on questions of political economy, its insistence on a historical sensitivity and its scepticism of a politics of interventionism. The two fields are also criticized in similar terms, including their tendency towards over-generalization and distance from issues relevant to practice. We argue that these disciplines can learn from one another's strengths and weaknesses, thereby enriching discourses and practices of critique.
\end{abstract}

\section{Introduction}

On 18 March 2018, President Rodrigo Duterte of the Philippines announced his intentions to withdraw from the Rome Statute of the International Criminal Court (ICC), 'effective immediately'. ${ }^{1}$ The announcement came just over a month after the Chief Prosecutor of the ICC, Fatou Bensouda, issued a statement that The Office of the Prosecutor was opening a preliminary examination of the situation in relation to the drug war in the Philippines. ${ }^{2}$ It was the second state to respond in this way. Burundi announced its withdrawal in October 2016, six months after a preliminary investigation into possible crimes against humanity was launched by the prosecution. ${ }^{3}$ In both states, the discourse surrounding withdrawal was permeated by accusations that the ICC served as an agent of Western interests. Whether this was political opportunism or a sustained attempt at resisting neo-colonialism, it is not only despots in the Global South who are raising concerns about international criminal justice. Critiques from the Global South are, furthermore, complemented by a disillusionment among supporters of international criminal law in the Global North.

Certainly, some of the discontent springs from the inherent problems generally attached to criminal justice, both domestically and internationally. From the point of view of victims,

\footnotetext{
* Padraig McAuliffe is Senior Lecturer University of Liverpool and Christine Schwöbel-Patel is Associate Professor, University of Warwick. We are grateful for the helpful comments from the reviewers. All errors remain our own. [P.G.Mcauliffe@liverpool.ac.uk] [Christine.schwobel-patel@warwick.ac.uk].

${ }^{1}$ H. Ellis-Petersen, 'Rodrigo Duterte to Pull Philippines out of International Criminal Court', The Guardian, 14 March 2018.

2 Statement of the Prosecutor of the International Criminal Court, 8 February 2018, available online at https://www.icc-cpi.int/Pages/item.aspx?name=180208-otp-stat (visited 17 August 2018).

${ }^{3}$ Human Rights Watch, 'Burundi: ICC Withdrawal Major Loss to Victims: Latest Move Shows Government's Disregard for Victims' (2016), available online at https://www.hrw.org/news/2016/10/27/burundi-iccwithdrawal-major-loss-victims (visited 17 August 2018).
} 
this may be summarized as — 'we ask for justice, you give us law'. ${ }^{4}$ More specifically to international criminal law, as a result of the political constraints, selectivity, costliness and inordinate lengths that inhere in international criminal trials, claims regarding its so-called 'post-romantic' phase are no longer unusual. ${ }^{5}$ Despite the continuous reference to the discipline's youth, after more than a decade of reflection on the lessons of the ad hoc tribunals and 16 years of an active ICC, some of the voices of discontent about international criminal law as a project have emerged as a sustained challenge to its rationale. What has emerged are a number of scholarly projects that challenge the assumptions on which the institutions of international criminal law are premised and that interrogate in a deeper way how power circulates within the field of international criminal law. Indeed, some now argue that 'the critical note has come to dominate the discourse'. ${ }^{6}$ The body of critique loosely bundled under critical approaches to international criminal law represents a sustained, if not necessarily coherent, attempt at finding a common critical note. Despite that it is an informal and multifarious network, critical approaches to international criminal law provide a platform for a distinct way of thinking about international criminal law as a field of contestation over meaning, methods and solutions - a means by which concerns about its regulative and symbolic functions is formulated. ${ }^{7}$ It both builds on and supplements concurrent feminist, ${ }^{8}$ and third world approaches to international law, ${ }^{9}$ both of which represent critiques that interrogate the embedded political, economic and gender biases held by international criminal law.

Overall, the impact of this structural critique on policy or practice has been minor. ${ }^{10}$ Indeed, the impact of structural critique on more mainstream scholarship is also questionable. It is productive, therefore, to examine how other disciplines have attempted to bridge gaps between mainstream and critical scholarship as well as theory and praxis. One critical field that we suggest offers valuable insights is the critique of liberal peacebuilding, which shares many of the same concerns about peacebuilding as a liberal project as critical approaches to international criminal law holds about international criminal law. Notably, the liberal peacebuilding critique has moved beyond a deconstruction phase to what can be described as an emancipatory one. In other words, it is developing a counter-project to liberal peacebuilding, enduring its own difficulties in deciding whether to engage the mainstream, thereby gaining

\footnotetext{
${ }^{4}$ K.M. Clarke, "We Ask for Justice, You Give Us Law": The Rule of Law, Economic Markets and the Reconfiguration of Victimhood', in C. De Vos, S. Kendall and C. Stahn (eds), Contested Justice: The Politics and Practice of International Criminal Court Interventions (Cambridge University Press, 2015) 272.

5 P. Akhavan, 'The Rise and Fall, and Rise, of International Criminal Justice', 11 Journal of International Criminal Justice (2013) 527, at 527.

${ }^{6}$ D. Robinson, 'Inescapable Dyads: Why the International Criminal Court Cannot Win', 28 Leiden Journal of International Law (2015) 323, at 324. Others disagree. Michelle Burgis-Kasthala, for example, argues that 'the dominant paradigm informing ICL [international criminal law] scholarship is a positivist, liberal one which favours doctrinal writing or at most, discourse analysis about the normative underpinnings of the ICL project'. See M. Burgis-Kasthala, 'Scholarship as Dialogue? TWAIL and the Politics of Methodology', 14 Journal of International Criminal Justice (2016) 921, at 927.

7 C. Schwöbel, 'Introduction', in C Schwöbel (ed.), Critical Approaches to International Criminal Law (Routledge, 2015) 1.

${ }^{8}$ See, for example, L. Chappell, The Politics of Gender Justice at the International Criminal Court: Legacies and Legitimacy (Oxford University Press, 2015); F. Ní Aoláin, 'Gendered Harms and their Interface with International Criminal Law: Norms, Challenges and Domestication', 16 International Feminist Journal of Politics (2014) 622.

${ }^{9}$ See symposium of Journal of International Criminal Justice on third world approaches to international law and the ICC, edited by Asad Kiyani, John Reynolds and Sujith Xavier, in 14 Journal of International Criminal Justice (2016) 915-1009.

${ }^{10}$ It is notable that there are emerging efforts at integrating structural critique in international criminal law into advocacy work. See, for example, the Global Legal Action Network, which works with innovative legal strategies. Several members of the Legal Action Committee are also engaged in scholarly work around the critical approaches to international criminal law project. See the website of the Global Legal Action Network, available online at http://www.glanlaw.org/about-us (visited 17 August 2018).
} 
the attention of that mainstream and facing its own counter-critique. These are challenges that any critical orientation faces and yet they hold particular interest to the project of critical approaches to international criminal law with regard to its substantive parallels of critique, namely a sensitivity to questions of political economy, an insistence on historical sensitivity and skepticism of a politics of interventionism.

In the following, we examine the development of both critical approaches to international criminal law and peacebuilding. We then discuss the similarities in the critiques between the two disciplines. We follow this with an examination of emergent counter-critiques and their possible crises of relevance. Finally, we draw some tentative conclusions.

\section{The Justice Project, the Peace Project and Their Critics}

International criminal law is a project that has multiple goals, emphasizing the need for justice in the courtroom for a society that has experienced mass atrocity to be able to transition to a peaceful one. The growth of international criminal law, as a body of rules and practices, has spawned ad hoc tribunals, hybrid courts and the permanent ICC, as well as a surrounding industry of judges, lawyers and administrators as well as non-governmental organizations and activists, scholars, think-tanks, specialized journals and university programmes. The core principles that unite this disparate coterie of persons and institutions include a fidelity to the principles of both individual criminal responsibility and due process, a desire to bring to justice the 'big fish' over the 'small fry' and the elevation of the needs of humanity over traditional principles of immunity. International criminal law is grounded in both deontological and consequentialist claims. Deontologically, international criminal law assumes that rational individuals enjoy volition, act in accordance with what their rationality dictates and fundamentally enjoy autonomy over their actions. As a result, they should be punished whenever and wherever this leads them to commit (mass) atrocity. As such, international criminal law is a classically liberal project that attempts 'to fix individual responsibility for history's violent march'. ${ }^{11}$ This is accompanied by consequentialist claims about deterrence of violence, ${ }^{12}$ the importance of the rule of law $^{13}$ and alleviation of suffering. ${ }^{14}$

Prior to the recent critical turn, scholarship in international criminal law was characterized by an 'overly protective' literature given the reluctance to criticize a nascent ICC with powerful detractors. ${ }^{15}$ It follows that the historical evolutionary tale was one which emphasized progress. From recognition of individual criminal responsibility for gross human rights abuses to a permanent international court underpinned by a multilateral treaty ratified by the majority of the world's states. It incorporated a whiggish teleology of law against politics, reason against passion, right against might. International criminal law, therefore, employs a highly evocative

11 A. Marston Danner and J.S. Martinez, 'Guilty Associations: Joint Criminal Enterprise, Command Responsibility, and the Development of International Criminal Law', 93 California Law Review (2005) 75, at 75.

${ }^{12}$ T. Meron, 'The Case for War Crimes Trials in Yugoslavia', in T. Meron (ed.), War Crimes Law Comes of Age (Oxford University Press, 1998), at 187, 196, 10. See also the jurisprudence on deterrence, for example, in Judgment, Rutaganda (ICTR-96-3-T), Trial Chamber, § 456, 6 December 1999. For a critical view, see P. McAuliffe, 'Suspended Disbelief: The Curious Endurance of the Deterrence Rationale in International Criminal Law', 10 New Zealand Journal of Public and International Law (2012) 227.

${ }^{13}$ Fatou Bensouda comments: 'The mission to entrench the rule of law and attain normative global justice is a continuous journey that has seen the emergence and increasing acceptance of international criminal law as pivotal and indispensable in the fight against impunity'. See F. Bensouda, 'A Tribute to Adam Dieng', in C.R. Majinge (ed.), Rule of Law Through Human and International Criminal Justice: Essays in Honour of Adam Dieng (Cambridge University Press, 2015) 48.

${ }^{14}$ J.J. Savelsberg, 'International Criminal Law as One Response to World Suffering: General Observations and the Case of Darfur', in R.E. Anderson, Alleviating World Suffering: The Challenge of Negative Quality of Life (Springer, 2017) 361.

${ }^{15}$ Robinson, supra note 6, at 324. 
vocabulary redolent of heroism, if not messianism — it combats 'radical evil', prosecutes 'the worst of the worst' and sets itself in existential opposition to persecution, mass murder, rape and torture. The ad hoc tribunals and ICC statutes were seen as a welcome institutionalized affirmation of absolute moral sentiments that went unrealized for so long. ${ }^{16}$ The expectation was that international criminal law could and would 'exert broad influence on both the development of international humanitarian law and its humanization'. ${ }^{17}$

\section{A. The Critique of International Criminal Law}

As Frédéric Mégret acknowledges, all those involved in assessing international criminal law are in some way critical; few, if any, of its defenders engage in full-blooded apologias for it. ${ }^{18}$ Admissions that the honeymoon is over are common place. ${ }^{19}$ However, before the aforementioned critical literatures emerged and voices from the Global South were heard in the silos and echo-chambers of The Hague, Geneva and New York, the most common and prominent critiques were those from a positivist tradition which focused on the effectiveness of existing structures and how they could be strengthened. Far from amounting to a deep engagement with the politics of the field, much of the criticism of international criminal law was pragmatic and policy-oriented advice aiming to make its institutions better at dealing with the complexities that face it, "tak[ing] the "big questions as answered" and work[ing] from within limitations that are more or less taken for granted and not necessarily seen as problematic'. ${ }^{20}$ Much mainstream critique effectively constitutes a mild concession of the field's imperfections tempered by renewed statements of unqualified faith in its promise and progress if these blemishes can be effaced. ${ }^{21}$ Problems with international criminal law continue to be posed as issues of implementation, not orientation - of communication, not perpetuation of inequalities. As such, these more mainstream criticisms are best described as an efficiency critique, rooted in liberalism and concerned that international criminal law has failed to live up to its values - due process, independence, modes of responsibility and complementarity - or to its promise - accountability, expressionism and more peaceful states. ${ }^{22}$ As Michelle BurgisKasthala puts it: "If "setbacks" are acknowledged, a range of responses centering on a lack of enforcement and suggestions for improvement ensure that the progress narrative prevails.' 23

The critique set forth under critical approaches to international criminal law, by contrast, does not evaluate international criminal law on the basis of success or failure in these areas, but rather explores the presumptions that international criminal law is inherently humanizing, healing, emancipatory or dignifying. ${ }^{24}$ It asks who benefits from the existing parameters of international criminal law, who loses through them and why. It is this reorientation from a technical to a structural critique which marks out critical approaches to international criminal law as a distinctive form of criticism. Whilst positivist critiques tended

\footnotetext{
16 A. Cassese, 'Reflections on International Criminal Justice', 61 Modern Law Review (1998) 1.

17 T. Meron, 'The Humanization of Humanitarian Law', 94 American Journal of International Law (2000) 239, at 243

18 F. Mégret, 'International Criminal Justice: A Critical Research Agenda', in C. Schwöbel (ed.), Critical Approaches to International Criminal Law (Routledge, 2015) X, at 17-18.

${ }^{19}$ D. Luban, 'After the Honeymoon: Reflections on the Current State of International Criminal Justice', 11 Journal of International Criminal Justice (2013) 505, at 509.

${ }^{20}$ Mégret, supra note 18 , at 18.

${ }^{21}$ T. Krever, 'International Criminal Law: An Ideology Critique', 26 Leiden Journal of International Law (2013) 701 , at 710 .

${ }^{22}$ Schwöbel, supra note 7.

${ }^{23}$ Burgis-Kasthala, supra note 6, at 927.

${ }^{24}$ S. Kendall, 'Critical Orientations: A Critique of International Criminal Court Practice', in C. Schwöbel (ed.), Critical Approaches to International Criminal Law (Routledge, 2015) X, at 59.
} 
to reaffirm the benefits of the inherent liberalism of international criminal law, such critiques started from the position of the ICC's powerlessness in the world of politics. For those interested in structural problems, many of the issues in international criminal law lie in its embeddedness within a liberal, colonialist or gendered legal paradigm. These rules enable the power held by institutions of international criminal law. For these critics, analysis of power relations between international criminal law, the international community and subject states is too often excluded within scholarship that is already convinced of the immunity of international courts and tribunals from politics and overwhelmingly oriented towards positivist assessment of judgments and treaty provisions. ${ }^{25}$ Those (knowingly or unknowingly) connected to the project of critical approaches to international criminal law aim to acknowledge the politics of international criminal law by not necessarily rejecting a political role for the courts but emphasizing the need to understand these political dimensions and to question the type of politics enacted in individual cases. ${ }^{26}$ Without such acknowledgment, and bearing in mind its simplified moral messaging and ostensible aversion to political contention, international criminal law could become an all too comforting language with which to address crises and articulate human projects. ${ }^{27}$ The literature within critical approaches to international criminal law has developed a wide-ranging critique of the role of international criminal law in both the international global liberal architecture as well as the domestic states in which it intervenes. However, having come this far, the obvious question is what happens next? As Susan Marks argues, enquiry in ideology critique 'is motivated not only by curiosity alone, but also by a sense of injustice, a wish to break down barriers to the enjoyment of social goods' ${ }^{28}$

For some, the critique must be concerned not only with deconstruction but with empowerment, openly serving a better politics, erring on the side of engagement that is empowering and sensitive, not imposing or chauvinistic. To the extent that it embraces this mission, critique becomes an unabashedly political project, concerned with more than mere rejectionism, testing the assumptions of international criminal law to redirect its attention to new possibilities. ${ }^{29}$ To the extent that engaging positively is successful, can concern and commitment realistically be transmuted into emancipatory projects in the context of the institutional limitations of international criminal courts and tribunals and international criminal justice at large? If critical scholars are to constructively engage with questions of criminal justice, must critical distance necessarily give way to the compromises and complicities of involvement? In answering these questions, we suggest that there are lessons to be learned from the liberal peacebuilding critique which followed a similar trajectory from disparate critical appraisals of post-conflict peacebuilding activities to a reasonably coherent (though far from uniform) body of study to pondering the question of policy relevance and/or complicity.

\section{B. Critique of Liberal Peacebuilding}

In contexts of post-conflict states ravaged by war, broken institutions and political instability, peacebuilding is usually labelled 'liberal' because it is generally conducted by western liberal states, whose interventions are underpinned by liberal motivations, most notably the response to actual or foreseen mass breaches of human rights. In addition, such states pursue liberal

\footnotetext{
${ }^{25}$ Ibid., at 56-57.

${ }^{26}$ S. Nouwen and W.G. Werner, 'Doing Justice to the Political: The International Criminal Court in Uganda and Sudan', 21 European Journal of International Law (2011) 941.

${ }^{27}$ C. Schwöbel, 'The Comfort of International Criminal Law', 24 Law \& Critique (2013) 169, at 170.

${ }^{28}$ S. Marks, The Riddle of All Constitutions: International Law, Democracy and the Critique of ideology (Oxford University Press, 2000) 121.

${ }^{29}$ B. Sander, 'International Criminal Justice as Progress: From Faith to Critique', in M. Bergsmo et al. (eds), Historical Origins of International Criminal Law, Vol. 4 (Torkel Opsahl Academic EPublisher, 2015) 749, at 824.
} 
goals, such as democracy, rule of law and market economics. ${ }^{30}$ The core tenet of this paradigm is the assumption that the best grounding for peace within conflicted states is a liberal democratic polity and market-oriented economy. Central sites of peacebuilding practice and discussion include post-conflict Kosovo, Iraq, Afghanistan, the Democratic Republic of the Congo, Lebanon and Haiti, amongst others. Key institutions in the conceptualization and implementation of liberal peacebuilding techniques include the United Nations (UN), and within it the UN Peacebuilding Commission, the International Monetary Fund and the World Bank. The liberal peacebuilding model has primarily been criticized for its underwhelming empirical record. Civil war recurrence rates of around 67 per cent of post-conflict countries during the 1990s and nearly 90 per cent in the first decade of the 2000s sparked the initial attention of critics to the failure of the international community to end cycles of war and repression. ${ }^{31}$ Using various methodologies, scholars estimate that anything from 25 per cent to 50 per cent of intrastate peace settlements break down in the following five to ten years. ${ }^{32}$ Liberal peacebuilding has also been seen to fail on its own normative terms. Past peacebuilding missions have featured unwanted legacies of increased ethnic violence, public protest, grossly unequal economies, neopatrimonialism, electoral irregularities and gender disparities. The governments promoted or assisted by peacebuilding missions have consistently confronted challenges of legitimacy, capacity and economic underdevelopment. Poverty is rarely reduced even after significant international intervention. Many countries subjected to peacebuilding missions remain clustered at the bottom of the UN Development Programme's Human Development Report. As Roberto Belloni argues: 'It has become commonplace to state that liberal peacebuilding in war-torn states has, by and large, failed.' ${ }^{33}$

One of the reasons why the liberal peacebuilding critique is more established is that it has been around longer as a body of critique. While the main impetus for both peacebuilding and international criminal law dates back to the post-Cold War era of liberal interventionism beginning in the early 1990s, the critique developed at different paces. In part, this is most likely due to the close academic-practitioner link that has characterized international criminal law, arguably tempering critique. Many of the scholars concerned with international criminal law at the time (even if it was not yet a distinct discipline) were indeed instrumental in drafting the ICC Statute, some taking up key positions within the newly established tribunals. While international criminal law, therefore, enjoyed a prolonged period of general scholarly support well into the new century as the ad hoc tribunals grew in strength and the ICC came to life, critique of peacebuilding practice in the likes of Cambodia, Bosnia and Kosovo was underway by the end of the 1990s. ${ }^{34}$ The failings of peacebuilding were arguably both more evident and perhaps more catastrophic than the failures of international criminal law, and accordingly, a much larger critical literature built up over time. While critical approaches to international criminal law has thus far generated a small cannon and had an impact only at the margins of mainstream scholarship of international criminal law, so sustained and successful has the liberal peacebuilding critique become that it is credible to argue it is the 'new mainstream'. ${ }^{35}$

\footnotetext{
${ }^{30}$ D. Zaum, 'Beyond the Liberal Peace', 18 Global Governance (2012) 121, at 121-122.

${ }^{31}$ C. Call, Why Peace Fails: The Causes and Prevention of Civil War Recurrence (Georgetown University Press, 2012).

${ }^{32}$ See, for example, A. Suhrke and I. Samset, 'What's in a Figure? Estimating Recurrence of Civil War', 14 International Peacekeeping (2007) 195, which cites around 23 per cent; and P. Martin, 'Coming Together: PowerSharing and the Durability of Negotiated Settlements', 15 Civil Wars (2013) 332, at 334, citing a half.

${ }^{33}$ R. Belloni, 'Hybrid Peace Governance: Its Emergence and Significance', 18 Global Governance (2012) 21, at 21.

${ }^{34}$ For example, D. Chandler, Bosnia: Faking Democracy after Dayton (Pluto Press, 2000).

${ }^{35}$ S. Hameiri, 'A Reality Check for the Critique of the Liberal Peace', in S. Campbell, D. Chandler and M. Sabaratnam (eds), A Liberal Peace? The Problems and Practices of Peacebuilding (Zed Books, 2011) 191, at 192.
} 
Both fields of critique share similar starting points. Critical approaches to international criminal law interrogates the presuppositions that enchant international criminal lawers, challenges existing institutions by searching for obscured interests or class domination and is consciously sensitive to exclusions, oppressions and suppression. ${ }^{36}$ Similarly, the liberal peacebuilding critique is 'self-consciously radical, antithetical to realist analysis and rejects some of the dominant paradigms in peace research to concentrate on relatively neglected matters like underdevelopment and social exclusion at the level of individuals and communities that more orthodox analyses ignore' ${ }^{37}$ Critics of liberal peacebuilding ask how peacebuilders produce and reproduce its authoritative claims, akin to critics of international criminal law. Like the latter, they ask what forms of power are present in the object of their enquiry and how such forms of power are obscured within the technical language of policy documents, the principle of the Responsibility to Protect and the ICC Statute. Just as critics of international criminal law unsettle assumptions that international criminal courts and tribunals are inherently dignifying and legitimate, peacebuilding critics unsettle assumptions of democracy, statebuilding and liberalized economies as inherently pacific. Even some of the self-identified weaknesses are similar. While Immi Tallgren admits the intrusions of the critique of international criminal law may be necessarily 'crude' ${ }^{38}$ and Mégret accepts the allegations of occasional 'posturing' in the critique, ${ }^{39}$ Roger Mac Ginty concedes that, at times, the critique of peacebuilding has gone 'far beyond the boundaries of careful and value-free academic discourse'. ${ }^{40}$ Even the future development of both fields engendered similar doubts. Contributions under critical approaches to international criminal law ponder an irrelevance or absorption dilemma, namely that critique is confined to either irrelevance in practice or absorption in the very liberal project it critiques. ${ }^{41}$ In the same vein, critics of peacebuilding wrestle with the question whether they 'should follow the red herring and present alternative "blueprints" or remain true to its own raison d'être, by pointing out contradictions, engaging with strategic discourses, increasing context sensitivity from within'. ${ }^{42}$

The aptness of the liberal peacebuilding critique as a comparator for critical approaches to international criminal law is best illustrated by the similarity of theoretical approaches. Critique of international criminal law is divided between the effectiveness critique from liberalism and a more radical critique of liberalism, and correspondingly, criticism of peacebuilding is divided by two main schools that could be roughly distinguished as the moderate policy-oriented ideas-based critique, on the one hand, and the radical power-based critique, on the other. ${ }^{43}$ The radical critiques of liberalism are suspicious of Western interventionist rationales, seeing the discursive techniques that emphasize free politics and open markets as a façade behind which Western hegemony is concealed, self-interest is obfuscated and exploitative global structures are legitimated. By contrast, and echoing the positivist, effectiveness-based criticism of international criminal law, the more policy-oriented,

\footnotetext{
${ }^{36}$ I. Tallgren, 'Who Are "We" in International Criminal Law? On Critics and Membership', in Schwöbel (ed.), Critical Approaches to International Criminal Law (Routledge, 2015) X, at 75.

${ }^{37}$ R. Mac Ginty, International Peacebuilding and Local Resistance: Hybrid Forms of Peace (Palgrave Macmillan, 2011), at 22-23.

38 Tallgren, supra note 36 , at 89.

${ }^{39}$ Mégret, supra note 18 , at 44.

${ }^{40}$ Mac Ginty, supra note 37, at 23.

${ }^{41}$ Mégret, supra note 18 , at 45.

42 S. Tadjbakhsh and O. Richmond, 'Conclusion: Typologies and Modifications Proposed by Critical Approaches', in S. Tadjbakhsh (ed.), Rethinking the Liberal Peace: External Models and Local Alternatives (Routledge, 2011) 221, at 233.

43 These distinctions are drawn in T. Paffenholz, 'Unpacking the Local Turn in Peacebuilding: A Critical Assessment Towards an Agenda for Future Research', 36 Third World Quarterly (2015) 857, at 861; D. Chandler, International Statebuilding: The Rise of Post-Liberal Governance (Routledge, 2010) 24.
} 
moderate critiques of peacebuilding accept the legitimacy of liberal values and intervention, but contend that political and economic reforms need to be modulated or delayed on the basis that post-conflict and developing world states are unsuited to their prescriptive rationalities. ${ }^{44}$ Policy-oriented critiques judge peacebuilding interventions for their failure to either live up to their own aspirations and norms or their failure to inculcate them domestically. On the ground, moderate critics are concerned with sequencing interventions and reforms to guarantee liberal outcomes in the long run. They do not question the implicit value of liberalism and so maintain an inherently conservative status quo. Power-based critics, by contrast, seek a radically different post-liberal peace and are suspicious of the inequalities inherent in global power relations that revolve around the interests of the Global North and a Eurocentric weltanschaung. The tendency of problem-solvers in both peacebuilding and international criminal law to 'work with what we've got' represents a missed opportunity 'to interrogate the order itself and, by accepting it as "reality", re-inforces its underlying values and structures'. ${ }^{4}$

\section{Parallel Critiques}

Given the similarities displayed by the critique and obvious political sympathies, it is curious that the literature under critical approaches to international criminal law has yet to fully engage with the liberal peacebuilding critique in a systematic way and vice versa. If, as argued below, statebuilding represents a policy of global securitization, democracy a form of global political homogenization and marketization a core element of a globalized economy, it is possible to consider that international criminal law is the legal dimension of peacebuilding. Just as peacebuilders attribute conflict to the lack of a state, democracy and/or a market, international criminal law ascribes instances of mass atrocity to the absence of criminal accountability which leaves military and political power with an essentially untrammeled power to abuse their own or neighboring populations. Like peacebuilding, international criminal law views itself as a core element of conflict management. ${ }^{46}$ Indeed, the Office of the Prosecutor of the ICC implicitly acknowledges a type of division of labour in its insistence that its concern with the 'interests of justice' under Article 53 of the ICC Statute must be distinguished from the 'interests of peace' which falls within the mandate of other institutions, most notably the Security Council. ${ }^{47}$ Like statebuilding, democratization and economic liberalization, international criminal law appears a standard solution to ethnic conflict, virulent nationalism and religious fundamentalism. ${ }^{48}$ Although international criminal law may not directly build a state, impose forms of democratic rule or open economies further, it is, nevertheless, seen by its critics as a form of power which has a bias for securitization, homogenization and marketization.

In the following, we have organized what we see as the most important overlaps of critique and agenda in the two critical projects. While they are intertwined and interdependent, the points of critique which we are highlighting consider: first, the politics behind the technocratic language of intervention; second, the hegemonic impulses behind the projects of

\footnotetext{
${ }^{44}$ See, for example, R. Paris, At War's End: Building Peace After Civil Conflict (Cambridge University Press, 2004).

${ }^{45}$ M. Pugh, 'The Political Economy of Peacebuilding: A Critical Theory Perspective', in A. Bellamy and P. Williams (eds), Peace Operations and Global Order (Routledge, 2005) 39, at 41.

${ }^{46}$ ICC Office of the Prosecutor, Policy Paper on the Interests of Justice (2007), at 4, available online at https://www.icc-cpi.int/iccdocs/asp_docs/library/organs/otp/ICC-OTP-InterestsOfJustice.pdf (visited 17 August 2018).

${ }^{47}$ L. Moreno-Ocampo, Keynote Address to Council on Foreign Relations, Washington, D.C. (2010), at 6, available online at www.cfr.org/content/publications/.../MorenoOcampo.CFR.2.4.2010.pdf (visited 17 August 2018).

${ }^{48}$ A view outlined but not shared in D. Zolo, 'Peace Through Criminal Law?' 2 Journal of International Criminal Justice (2004) 711, at 727.
} 
peacebuilding and international criminal law; third, the enabling of economic liberalism through projects of peacebuilding and international criminal law; and finally, complicity in conservative domestic politics. This ordering, apart from its inherent overlaps, also needs further qualification. The critical literature in both fields is far from homogenous; not only is critique different in its emphasis, it is also constantly moving in its subject-matter. Regardless of these differences, we believe that there are, nevertheless, strong affinities, both within the respective fields as well as across them, which are worth highlighting.

\section{A. Revealing the Politics behind Technocratic Language}

Perhaps the area with the greatest similarity between liberal peacebuilding critique and the critique of international criminal law is the challenge of naive technicism displayed in the selfpresentation of those promoting peace and justice. Instead of questioning structural inequalities, those promoting liberal peace and international criminal law focus on technical issues which improve the process in question. Critics argue that peacebuilders apply a standardized toolbox consisting of elections, civil service, the justice sector, army and police to widely varying conflict ecologies. These approaches 'are inclined to see state-building as a matter of simple technology, as a set of technical skills or capacities, each of which can be acquired, refined and applied no matter what the context ... . They imply that each post-conflict problem has a logical state-building solution. ${ }^{49}$ In taking issue with peacebuilding's selfpresentation as an apolitical technology, critics argue that problems of rule and control that revolve around state weakness are not the key dilemmas, but rather questions of allocations of resources. ${ }^{50}$ Statebuilding and good governance reframe public policy 'not as an inherently political matter pertaining to conflict between competing and often irreconcilable interests, but as a matter of "expertise" and "good" management". 51

Indeed, to the extent that peacebuilding is content to leave these inequalities in place, this technical expertise serves as veiled ideological camouflage for the pathologies of peacebuilding. ${ }^{52}$ Above all, technical activities like capacity building serve to operationalize the transnationalization of the state and legitimize external political interference on a grand scale. ${ }^{53}$

International criminal law rests on the same universalist presumptions as democratization, statebuilding and the free market. Law within the narrative of international criminal law can and must be considered on the basis of universal principles of justice, regardless of political pressures emanating from sovereignty, state boundaries, amnesty or positions as head of state. The ICC and ad hoc tribunals self-present as fundamentally legalist enterprises in the Shklarian sense, animated by 'the ethical attitude that holds moral conduct to be a matter of rule, and moral relationships to consist of duties and rights determined by rules'. ${ }^{54}$ Law enjoys an inherently superior position as neutral and objective justice, understood in contradistinction to 'the unprincipled desultoriness and unpredictable vacillation of

\footnotetext{
${ }^{49}$ B. Bowden, H. Charlesworth and J. Farrall, 'Introduction', in B. Bowden, H. Charlesworth and J. Farrall (eds), The Role of International Law in Rebuilding Societies after Conflict: Great Expectations (Cambridge University Press 2009) X, at 5-6.

${ }^{50}$ M. Berdal and D. Zaum, 'Power After Peace', in M. Berdal and D. Zaum (eds), Political Economy of Statebuilding: Power after Peace (Routledge, 2013) 1, at 11.

51 S. Hameiri, Regulating Statehood: State Building and the Transformation of the Global Order (Palgrave Macmillan, 2010) 6.

52 O. Richmond and J. Franks, Liberal Peace Transitions: Between Statebuilding and Peacebuilding (Edinburgh University Press, 2009) 182.

${ }^{53}$ S. Hameiri, 'Capacity and its Fallacies: International State building as State Transformation', 38 MillenniumJournal of International Studies (2009) 72.

${ }^{54}$ J. Shklar, Legalism: Law, Morals, and Political Trials (Harvard University Press, 1964), at 1.
} 
politics' ${ }^{55}$ The ICC's Office of the Prosecutor consistently denies that politics has anything to do with justice. Bensouda argues that the officials of the ICC 'have nothing to do with politics' even if she recognizes 'we operate in a political atmosphere'. ${ }^{56}$ While there is an element of public relations about this claim, this underpins how central the self-projection by international criminal law of speaking law to power is to the project overall. ${ }^{57}$ Given their stated commitment to explicate the problems attached to interventionism by international criminal law, it comes as no surprise that critics of international criminal law are skeptical of this presentation as merely legal technique as opposed to power. Building on a tradition of critical legal studies, it is argued that although the prosecution of the ICC acts as if law were neutral, the discourses of international justice operate ideologically, masking the reproduction of political relations of power and inequality behind the façade of technique and impartiality. ${ }^{58}$ The binary of individual guilt and innocence obscures the historical reality that mass inequality and abuse can never be the responsibility of a few individuals. Just as peacebuilding reduces issues of opportunity and social responsibility to prefabricated institutions, complex political, social, economic and moral questions over historic culpability and distribution are reduced by international criminal law to ritualized legal maxims. As such, Tallgren argues it naturalizes and excludes from the political battle 'certain phenomena which are in fact the pre-conditions for the maintaining of the existing governance'. 59

\section{B. Agents of Hegemony}

The critical peacebuilding school, moreover, interrogates the relationship between postconflict intervention and global governance. Peacebuilding is advocated by its supporters on the basis of consensual intervention to first stabilize states and then build harmonious societies after internal conflict. Peacebuilding critics see this form of governance as a tool imposing Western values about security, the state and economy to facilitate hegemonic control and exploitation of developing countries in a globalized world. ${ }^{60}$ They believe that pressures of self-disciplining and a culture of hegemony are at work, curbing the self-determination of intervened-upon societies while disavowing the open exercise of power and abjuring any responsibility for its actions. Mark Duffield, for example, argues that statebuilding constitutes an extension of international power over both the physical and political bodies of a population to secure a Western mass consumerist society from dangerous societies beyond its borders. By saving, developing and securing the other, prolonged external intervention is justified. ${ }^{61}$ The West's peacebuilding agenda clouds its exercise of power in humanitarian rhetoric, institutionalizing asymmetries of power it benefits from instead of levelling a grossly uneven global playing field. ${ }^{62}$

Many of these criticisms are replicated in international criminal law. International criminal law, and particularly the ICC, is both symptomatic and productive of the generation of global peace and security. The preamble to the ICC Statute causally links the fight against

\footnotetext{
${ }^{55}$ M. Drumbl, 'The Future of International Criminal Law and Transitional Justice', in W. Schabas, Y. McDermott and N. Hayes (eds), The Ashgate Research Companion to International Criminal Law (Ashgate, 2013 ), at 532.

${ }^{56}$ Fatou Bensouda, as quoted in P. Airault and B. Walker, Fatou Bensouda: The Victims are African (2011), available online at http://www.theafricareport.com/index.php/news-analysis/ fatou-bensouda-the-victims-areafrican-50178052.html (visited 17 August 2017).

${ }^{57}$ Luban, supra note 19, at 509.

${ }^{58}$ Krever, supra note 21, at 704-705.

${ }^{59}$ I. Tallgren, 'The Sensibility and Sense of International Criminal Law', 13 European Journal of International Law (2002) 561, at 594-595.

${ }^{60}$ D. Roberts, Liberal Peacebuilding and Global Governance: Beyond the Metropolis (Taylor \& Francis, 2011).

${ }^{61}$ M. Duffield, Development, Security and Unending War: Governing the World of Peoples (Polity Press, 2007).

${ }^{62}$ D. Chandler, Empire in Denial: The Politics of State-building (Pluto Press, 2006).
} 
impunity with the 'peace, security and well-being of the world'. The crimes punished are those 'most serious crimes of concern to the international community', an idea best captured in the notion of crimes against humanity which suggests the crimes are committed symbolically, if not actually, against everyone on the planet. The means by which it does this - beyond the physical containment of arrestees - is through deterrence whereby the threat of punishment serves to rein in the actions of would-be malefactors in the situation under investigation, while the absence of punishment inevitably encourages further cycles of violence. ${ }^{63}$ However, critics of international criminal law argue that it manifests forms of securitized Western hegemony, legitimizing and upholding the existing division of power and privilege in the global order as an agent of global justice. Since the conflicts in the former Yugoslavia and Rwanda, the Security Council has spoken the language of criminal accountability, establishing or helping to establish the ad hoc tribunals in The Hague and Arusha as well as hybrid tribunals in East Timor, Kosovo, Lebanon, Cambodia and Sierra Leone, to say nothing of the referrals of the situations in Darfur in 2005 and Libya in $2011 .{ }^{64}$ The ability of the Security Council to make referrals to the ICC under Article 13(b) of the ICC Statute and ask for deferral of investigations for a renewable period of 12 months pursuant to Article 16 of the ICC Statute leaves it open to the criticism that 'it is a tool for the exercise of the culture of superiority and to impose cultural superiority'. ${ }^{65}$ Though the ICC does not exercise direct control over states subject to investigations, the formal and informal threats and incentives it employs shape domestic policy, arguably replicating a modern form of justice civilsatrice oriented more towards global than domestic priorities. ${ }^{66}$ Complementarity, in particular, increasingly resembles a disciplinary exercise that privileges conformity with the ICC Statute over legal pluralism. ${ }^{67}$

The implications of the role held by international criminal law in reinforcing global law and order have alarmed many within the scholarship of critical approaches to international criminal law. The moderate form of worry is that international criminal tribunals could serve as an alibi for inaction in those areas too marginal to international interests, 'instruments of therapeutic governance, providing an acceptable compromise between despicable apathy and authorisation of military interventions that UN members are unwilling or unable to carry out: if not peace, then justice'. ${ }^{68}$ The greater worry, however, relates to the ICC as an active intervener. Commission of war crimes can serve to justify Western intervention in the interests of humankind by delegitimizing regimes and individuals, for example, in relation to Saddam Hussein in Iraq ${ }^{69}$ and Muammar Ghaddafi in Libya. ${ }^{70}$ As Barrie Sander argues, powerful states 'have been able to instrumentalise the stigmatising power of international criminal courts both as a means to undermine the legitimacy of their enemies and to justify military campaigns against them in the name of supporting the cause of global justice' ${ }^{71}$

\footnotetext{
${ }^{63}$ L. Moreno-Ocampo, 'The International Criminal Court - Some Reflections', 12 Yearbook of International Humanitarian Law (2009) 3, at 5.

${ }^{64}$ SC Res. 1593, 31 March 2005; SC Res. 1970, 26 February 2011.

${ }^{65}$ Statement of Mr. Erwa (Sudan), UN Doc. S/PV.5158, 31 March 2005, at 12.

${ }^{66}$ C. Stahn, 'Justice Civilsatrice? The ICC, Post-Colonial Theory, and Faces of "the Local"', in C. De Vos, S. Kendall and C. Stahn (eds), Contested Justice: The Politics and Practice of International Criminal Court Interventions (Cambridge University Press, 2015) 46, at 56-57.

${ }^{67}$ C. De Vos, 'All Roads Lead to Rome: Implementation and Domestic Politics in Kenya and Uganda', in C C. De Vos, S. Kendall and C. Stahn (eds), Contested Justice: The Politics and Practice of International Criminal Court Interventions (Cambridge University Press, 2015) 379.

${ }^{68}$ S. Nouwen, 'Justifying Justice', in J. Crawford and M. Koskenniemi (eds), The Cambridge Companion to International Law (Cambridge University Press, 2012) 327, at 343.

${ }^{69}$ E. Stover, H. Megally and H. Mufti, 'Bremer's Gordian Knot: Transitional Justice and the US Occupation of Iraq', 27 Human Rights Quarterly (2005) 830.

${ }^{70}$ Human Rights Council, Report of the International Commission of Inquiry on Libya, UN Doc. A/HRC/19/68, 8 March 2012, $\S 139-147$.

${ }^{71}$ Sander, supra note 29 , at 803.
} 
A further strand in both critiques is the notion that intervention is highly selective. Peacebuilding critics assail the failed state thesis employed to justify interventions on the basis of its selectivity, bearing in mind that certain states sharing many of the same characteristics as supposedly failed states escaped any international involvement. Indeed, to some the failed state thesis smacks of a cynical construct employed by the international community as a flag of convenience during intervention. ${ }^{72}$ Similarly, critics of international criminal law identify selectivity as one of the primary symptoms of bias and hegemony in this field. While the ICC has 123 state parties, it does not bind major powers like the United States, China, Russia and India, though their interests are seldom mutually compatible. Mahmood Mamdani argues that under the direction of the Security Council, the ICC has become an integral part of the Responsibility to Protect regime that permits the legal normalization of certain types of violence, most notably Western counterinsurgency efforts in countries like Iraq, Afghanistan and Libya, while criminalizing the violence in other states. ${ }^{73}$ The overwhelming focus of the prosecution of the ICC on Africa in terms of its situations under investigation, with the single exception of Georgia, and the fact that it remains the only continent where it has issued arrest warrants against suspected criminals has fostered the perception that the ICC represents a European court for Africans. ${ }^{74}$

\section{Facilitation and Legitimization of Global Economic Liberalization}

Peacebuilding agencies, most notably those in the UN, collaborate with the International Monetary Fund in joint frameworks for supporting statebuilding, engage in mutual consultations over coordination and make the international financial institutions, including the International Monetary Fund and the World Bank, and other institutional donors, core partners in peacebuilding activities. ${ }^{75}$ Although the international financial institutions pay lip-service to the distinctiveness of post-conflict countries and elaborate different policy agendas for them, the end-goal remains fundamentally the same as in any underdeveloped state, namely using governance 'to make the state safe for the market' by ensuring it is amendable to economic discipline, implement laws necessary for liberalization and withdraw from determining development goals. ${ }^{76}$ At a time when the state most needs to be active in protecting the economy through tariffs or providing for the citizenry through subsidies, "the most conservative and limiting' of neo-liberal economic models like privatization of state and parastatal businesses, private sector led growth, macroeconomic stabilization, including inflation and deficit reduction, and service-cutting budgetary management is imposed. ${ }^{77}$ In the critical peacebuilding literature, institutional governance reform and statebuilding are seen as a core aspect of the globalization of capital, ${ }^{78}$ while a liberal market is seen as inextricably bound with

\footnotetext{
${ }^{72}$ E. Newman, 'Failed States and International Order: Constructing a Post-Westphalian World', 30 Contemporary Security Policy (2009) 421.

${ }^{73}$ M. Mamdani, 'Responsibility to Protect or Right to Punish?' 4 Journal of Intervention and Statebuilding (2010) 53. A similar argument is made in D. Zolo, Victor's Justice: From Nuremberg to Baghdad (Verso, 2009, translated M.W. Weir) 30.

${ }^{74}$ A good treatment of the issue is found in T. Murithi, 'Between Political Justice and Judicial Politics: Charting a Way Forward for the African Union and the International Criminal Court', in G. Werle, L. Fernandez and M. Vormbaum (eds), Africa and the International Criminal Court (TMC Asser Press, 2014) 179.

${ }^{75}$ S. Woodward, 'The IFIs and Post-Conflict Political Economy', in M. Berdal and D. Zaum (eds), Political Economy of Statebuilding: Power after Peace (Routledge, 2013) X, at 141.

${ }^{76}$ R. Abrahamsen, Disciplining Democracy: Development Discourse and Good Governance in Africa (Zed Books, 2000) 525.

${ }^{77}$ S. Tadjbakhsh, 'Introduction: Liberal Peace in Dispute', in S. Tadjbakhsh (ed.), Rethinking the Liberal Peace: External Models and Local Alternatives (Routledge, 2011) X, at 29.

${ }^{78}$ D. Roberts, 'Hybrid Polities and Indigenous Pluralities: Advanced Lessons in Statebuilding from Cambodia' (2008) 2 Journal of Intervention and Statebuilding 63, 94.
} 
democratization. ${ }^{79}$ Peacebuilding is used less to address the root causes of conflict than to impose so-called 'disciplinary' or 'shock-therapy' neo-liberalism akin to traditional structural adjustment policies. ${ }^{80}$ The external critique is essentially that peacebuilding is a form of economic imperialism designed to protect the interests of the economic elite at the expense of post-conflict countries whose ability to generate basic legitimacy through meeting the needs of its citizens is eroded to a degree that makes future conflict more likely. ${ }^{81}$ As Volker Boege et al. argue, external actors who 'unscrupulously impose state-building in a very pragmatic fashion [are] not so much concerned about ideals of good governance, but about trade and monetary liberalization, property privatization and other interventions advantageous to external actors'. ${ }^{82}$ Essentially, though liberal peacebuilding is primarily based around non-market activities like elections and state-building, it is critiqued for doing nothing to challenge fundamentally unfair global economic structures, instead normalizing and legitimizing them.

Similarly, international criminal law is critiqued as a means of implicitly legitimating unfair economic structures and ignoring the distributive functions of its central precepts. Indeed, insofar as it prioritizes crimes that are less likely to occur in industrialized states, it is built on an inherent structural inequality between the Global North and Global South. ${ }^{83}$ Just as peacebuilders monopolize the political solutions to the roots of conflict in an unduly narrow manner, critics argue that international criminal law has arrogated the term justice to itself, thereby reducing the concept to criminal law when it could include economic and social justice. ${ }^{84}$ The stranglehold civil and political interpretations of human rights enjoys on the progressivist imaginations and social movements in the developing world has long been identified as a barrier to more socio-economically emancipatory thinking. ${ }^{85}$ Critics of international criminal law have long argued that individual criminal responsibility not only fails to properly situate crimes within a broader structural context underpinning suffering ${ }^{86}$ but that 'the overexposure of international criminal law blinds the world' to the types of slow, structural violence to which the same direct causality cannot be attributed as is found in international criminal law. ${ }^{87}$ Indeed, to the extent that international criminal law brings to justice mainly those within its remit who commit bodily integrity crimes, it implicitly exonerates those domestic and international actors who fall outside it who may have committed other abuses. ${ }^{88}$

\section{Complicity with Conservative Domestic Elites}

\footnotetext{
${ }^{79}$ Hameiri, Regulating Statehood, supra note 51, at 15.

${ }^{80}$ Mac Ginty, supra note 37, at 4.

${ }^{81}$ J. Smith, 'Economic Globalization and Strategic Peacebuilding', in D. Philpott and G. Powers (eds), Strategies of Peace (Oxford University Press, 2010) 247, at 247.

${ }^{82}$ V. Boege et al., 'Undressing the Emperor: A Reply to Our Discussants, in V. Boege et al. (eds), Building Peace in the Absence of States: Challenging the Discourse on State Failure (Berghof, 2009) 87, at 91.

83 C. Nielsen, 'From Nuremberg to The Hague: The Civilizing Mission of International Criminal Law', 14 Auckland University Law Review (2008) 81, at 107; C. Schwöbel-Patel, 'The Core Crimes of International Criminal Law', in K. Heller et al. (eds), Oxford Handbook of International Criminal Law (Oxford University Press, forthcoming 2019).

${ }^{84}$ Nouwen, supra note 68 , at 332.

${ }^{85}$ B. Rajagopal, International Law from Below: Development, Social Movements and Third World Resistance (Cambridge University Press, 2003) 171.

${ }^{86}$ Nielsen, supra note 83, at 99.

${ }^{87}$ S. Nouwen, "“As You Set out for Ithaka": Practical, Epistemological, Ethical, and Existential Questions about Socio-Legal Empirical Research in Conflict', 27 Leiden Journal of International Law (2014) 227, at 255. See also Clarke, supra note 4, at 276-277.

${ }^{88}$ R. DeFalco, 'Conceptualizing Famine as a Subject of International Criminal Justice: Towards a Modality-Based Approach', 38 University of Pennsylvania Journal of International Law (2017) 113.
} 
Peacebuilders practically operate under time and resource constraints, and in turn, are reliant on collaboration with, or lack of obstruction from, domestic leaders if their projects are to be brought about effectively. This gives the latter a diffuse but unambiguous veto power on rulership or state reconstruction, resulting in a dyadic relationship based on a mix of conflictual and co-operative strategies, a reality often described as 'compromised peacebuilding' ${ }^{89}$ Critics of peacebuilding argue that there is a natural tendency in such a system to depend on preexisting elites, often those with a strong inclination to maintain existing political and economic inequalities, to mediate issues of security to the exclusion of the many. ${ }^{90}$ As John Darby and Mac Ginty state, peacebuilding

often reinforces power-holders and replicates exclusive patterns of social and political relations ... in many peace processes, participants have been unwilling or unable to challenge prevailing patterns of social and political organization. Although violence ends, patterns of land ownership, patriarchy, and political participation remain unchanged. As a result, the 'peace' is essentially conservative rather than transformative. ${ }^{91}$

It is further argued that ostensibly liberalizing features like constitutionalization and the creation of power-knowledge systems like media, law, education and electoral democracy merely make ground for institutional stabilization. ${ }^{92}$ In a shell state willing to settle for such limited aims, there is a natural tendency to fall back on conservative models of peace as order that seek to make life 'predictable and relatively safe' to regulate conflict through security and coercion. ${ }^{93}$

The possibility that international criminal law serves to bolster conservative, if not abusive, domestic regimes is also one that animates its critics. International criminal law shares the need for dyadic, cooperative relationships with domestic regimes to an arguably even greater degree than peacebuilders. Being essentially free-standing institutions without police powers, international courts are in terms of enforcement strikingly weak - 'giants without limbs' in Antonio Cassese's famous terms - utterly reliant on the artificial limbs of state authorities to walk and work in the states to which they turn their attention. ${ }^{94}$ The ICC, for example, is entirely reliant on the assistance of states to arrest suspects, collect evidence, ensure access to witnesses, outreach and preserve the security of its personnel. In securing this cooperation, critics observe the ICC accommodating the governments of states whose assistance it needs, notwithstanding their own possible complicity in crimes. ${ }^{95}$ It is notable that in Uganda, the Central African Republic, the Democratic Republic of the Congo, Mali and Cote d'Ivoire, ICC proceedings have been directed solely against the 'rebels', that is, those acting against the present government or supporting political rivals. ${ }^{96}$ Inasmuch as it pursues prosecutions but

${ }^{89}$ M. Barnett and C. Zürcher, 'The Peacebuilder's Contract: How External Statebuilding Reinforces Weak Statehood', in R. Paris and T. Sisk (eds), The Dilemmas of Statebuilding: Confronting the Contradictions of Postwar Peace Operations (Routledge, 2009) 23.

${ }^{90}$ Belloni, supra note 33, at 31.

91 J. Darby and R. Mac Ginty, 'Introduction: What Peace? What Process?' in J. Darby and R. Mac Ginty (eds), Contemporary Peacemaking: Conflict, Violence and Peace Processes (Palgrave Macmillan, 2003) 1, at 6.

92 O. Korhonen, "The "State-Building Enterprise": Legal Doctrine, Progress Narratives and Managerial Governance', in B. Bowden, H. Charlesworth and J. Farrall (eds), The Role of International Law in Rebuilding Societies after Conflict: Great Expectations (Cambridge University Press 2009) X, at 16.

${ }^{93}$ M. Banks, 'Four Conceptions of Peace', in D. Sandole and I. Sandole-Staroste (eds), Conflict Management and Problem Solving: Interpersonal to International Applications (F. Pinter, 1987) 259, at 261.

${ }^{94}$ A. Cassese, 'On the Current Trends towards Criminal Prosecution and Punishment of Breaches of International Humanitarian Law', 9 European Journal of International Law (1998) 2, at 13.

95 P. Menon, 'Self-Referring to the International Criminal Court: A Continuation of War by Other Means', 109 AJIL Unbound (2016) 260.

${ }^{96}$ P. McAuliffe, 'From Watchdog to Workhorse: Explaining the Emergence of the ICC's Burden-sharing Policy as an Example of Creeping Cosmopolitanism', 13 Chinese Journal of International Law (2014) 259, at 281. 
leaves their governments essentially untouched, the ICC's discourse of ownership mimics the peace-as-order governance regimes of parallel peacebuilding efforts. ${ }^{97}$

\section{Future Trajectories: Steering a Path Between Irrelevance and Assimilation?}

For projects like critical approaches to international criminal law, critique often presents itself as a dialectic between irrelevance and assimilation. As regards irrelevance, critics of international criminal law may find themselves in the position of dangerous heretic, casually disdained with unreflective dismissals of cynicism and moral relativism, ignored because they proffer intellectual abstractions instead of solutions to the problems identified. ${ }^{9}$ Greater interaction with practice, by contrast, raises the diametrically opposed risk of complicity in replicating the terms and structures of the object of critique. ${ }^{99}$ Critical engagement is often to practitioners and advocates of international criminal law not merely something approximating sacrilege but also an active impediment to addressing its problems. ${ }^{100}$ Others, by contrast, believe the critique is, or at least should be, as concerned with empowerment as it is with deconstruction - the field cannot adopt a purely rejectionist attitude to international criminal law but should attempt to capture it for emancipatory outcomes or divert attention to new frontiers. ${ }^{101}$ This would fit with Philip Alston's recent counsel to creatively explore the art of the possible within real-world constraints and compromises, on the basis that too much critical scholarship is formulaic and insufficiently focused on means and methods to confront challenges identified. ${ }^{102}$ Based on the trajectories of the critical peacebuilding project, one might speculate on the options this seeming double bind presents for critics of international criminal law. Critical peacebuilding faces a similar dilemma whether to present alternative blueprints to the predominant approaches or remain true to its traditional mission of pointing out the pitfalls and contradictions of peacebuilding to increase context sensitivity from within the field. ${ }^{103}$ This reconsideration may have been spurred by the acknowledgment that, at least for some, the most significant failing of the critique 'has been its inability to engage in a fuller way' with the policy mainstream. ${ }^{104}$ Although peacebuilding scholarship remains dominated by critical perspectives, an intrinsic divide between 'optimistic practitioners' and 'pessimist or at least sceptical academics and theoreticians' remains in place. ${ }^{105}$ It became apparent that if critics were to remedy their lack of policy influence they would need to develop sharper theoretical tools to comprehend the complexities of liberal peacebuilding. ${ }^{106}$

\section{A. Irrelevance}

In contradistinction to conservative peacebuilding approaches emphasizing coercion and domination, critics of liberal peacebuilding have attempted to outline emancipatory models of

\footnotetext{
${ }^{97}$ V. Nesiah, 'Local Ownership of Global Governance', 14 Journal of International Criminal Justice (2016) 985.

98 Tallgren, supra note 36 , at 76, 81.

${ }^{99}$ M. Farrell, 'Critique, Complicity and I', in C Schwöbel (ed.), Critical Approaches to International Criminal Law (Routledge, 2015) X, at 96.

100 Nouwen, supra note 68.

${ }^{101}$ Sander, supra note 29, at 823.

102 P. Alston, 'The Populist Challenge to Human Rights', 9 Journal of Human Rights Practice (2017) 1, at 12-13.

103 Tadjbakhsh and Richmond, supra note 42, at 233.

104 O. Richmond and R. Mac Ginty, 'Where Now for the Critique of the Liberal Peace?' 50 Cooperation and Conflict (2015) 171, at 173.

105 Tadjbakhsh, supra note 77, at 1 . Tadjbakhsh also speaks of practitioners on the one hand and 'abstract theoreticians' on the other. See ibid., at 2.

106 J. Heathershaw, 'Towards Better Theories of Peacebuilding: Beyond the Liberal Peace Debate', 1 Peacebuilding (2013) 275, at 275.
} 
post-liberal peace. Instead of focusing on top-down security and institutions, it is proposed that peacebuilders enjoy closer relationships with those societies subjected to interventions and base their operations on local ownership and consent, with a greater concern for social justice and local agency. ${ }^{107}$ An ethical reading of peacebuilding is believed to require 'a willingness to recognize local ownership, human rights, culture, social and grass roots resources for selfgovernment' and 'infers an engagement with the everyday, to provide care, to empathize, and to enable emancipation'. ${ }^{108}$ It is argued that if local, elite and international visions of peace are connected by careful and sensitive partnership and without automatic deference to the expectations of interveners, then a social democratic and welfare-oriented state redistributing wealth via taxation and international subvention can and will emerge organically. ${ }^{109}$

However, critical visions of an alternative peace often suffer from a lack of detail and concrete tactical links to post-conflict politics. Visions of post-liberal peace tend to combine an emphasis on a wider and more diverse set of relationships within society with an ambitious wish list of outcomes, such as public service delivery, job security, employment and poverty alleviation. What is often missing is an agenda of how a wider set of relationships within society will lead to the desired outcomes. ${ }^{110}$ One such proposal, for example, is based on the idea of so-called 'unscripted conversations' between the local recipients of peacebuilding operations and other actors, elites and local communities around the type of peace they want. ${ }^{111}$ The type of democracy proposed is not one that links local consensus on peace to parallel elite efforts, but is instead a 'broader attitude towards governance, political community and life in general'. ${ }^{12}$ Questions of democracy and governance certainly need to be rethought. However, an issue which remains unaddressed is if such unscripted conversations lead to radically different conclusions within local communities about the type of peace they want, as might reasonably be expected in violently divided states. At which point can the 'ongoing critique' and 'the fluidity of continuous adjustment' be hardened to something more tangible? ${ }^{113}$ Interventions by peacebuilders on the ground which deal with issues of power, security or territory in a way that foregrounds (institutional) reform are regularly dismissed by critical theorists as problem-solving meta-narratives which maintain the status quo. ${ }^{114}$ Indeed, the temptation to focus exclusively on problematizing the ontological or epistemological claims of liberal interveners in isolation of an analysis of interventions on the lives of individuals or their environment, has the potential to leave critical theorists isolated from policy discourse on the ground. ${ }^{115}$ Peacebuilding critics have themselves acknowledged that a great deal of their work is as much about the field's ability to respond to the internal divisions and contradictions within

\footnotetext{
${ }^{107}$ Richmond and Franks, supra note 52, at 8.

108 O. Richmond, 'A Post-Liberal Peace: Eirinism and the Everyday', 35 Review of International Studies (2009) 557 , at 565 .

109 O. Richmond, 'The Impact of Socio-Economic Inequality on Peacebuilding and Statebuilding', 16 Civil Wars (2014) 449, at 464.

110 For example, E. Newman, 'A Human Security Peace-Building Agenda', 32 Third World Quarterly (2011) 1737, at 1751.

${ }^{111}$ Duffield, supra note 61, at 234.

${ }^{112}$ A. Mitchell and O. Richmond, 'Introduction: Towards a Post-Liberal peace: Exploring Hybridity via Everyday Forms of Resistance, Agency and Autonomy', in O. Richmond and A. Mitchell (eds), Hybrid Forms of Peace (Palgrave Macmillan, 2011) 1, at 17, quoting M. Chou and R. Bleiker, 'The Symbiosis of Democracy and Tragedy: Lost Lessons from Ancient Greece', 37 Millennium-Journal of International Studies (2009) 659, at 674.

113 Tadjbakhsh, 'Introduction', S. Tadjbakhsh (ed.), Rethinking the Liberal Peace: External Models and Local Alternatives (Routledge, 2011) X, at 7.

${ }^{114}$ O. Richmond, 'Resistance and the Post-Liberal Peace', Millennium: Journal of International Studies (2010) 665 , at 671.

115 S. Campbell, D. Chandler and M. Sabaratnam, 'Introduction: The Politics of Liberal Peace', in S. Campbell, D. Chandler and M. Sabaratnam (eds), A Liberal Peace? The Problems and Practices of Peacebuilding (Zed Books, 2011), at 3.
} 
peacebuilding discourses as it is about how those discourses transpire outside itself in the context of post-conflict ecology. ${ }^{116}$ Others admits that their critiques provide no functional way forward to an improved practice beyond problematizing and deconstructing liberal peacebuilding. ${ }^{117}$

Similarly, it is unclear whether the project of critical approaches to international criminal law has any potential remedial role for conflicted societies. This is partly due to the fact that structural critique often lies outside of the ambit of international criminal law. The observation that international criminal law is symptomatic of the politics of great powers, corporate power and domestic elites, creates the necessity of a deeper post-colonial and post-modern critique. Indeed, one of the key elements of the critique by critical legal studies of criminal law is that trial and judgment are inescapably tied to individual cases and not the vast web of economic, social and political structures that underpin an individual's resort to breaking the law. Even if the critique succeeded in fostering a willingness among international criminal courts to discuss the root causes of the crimes they process, it may not be met with a commensurate capacity to accurately capture it or propose responses. The critique is valuable in demonstrating international criminal law is not the remedy to the roots of conflict, but it may also make apparent that international tribunals are unlikely to generate any answers.

The critique of international criminal law is valuable, then, in showing how international criminal courts and tribunals could partly redress their deficit of legitimacy by engaging in an anti-hegemonic prosecutorial policy, altering their 'hero-savior' self-presentation or their instrumentalization of victims. (Only) these problems lie within the exclusive remit of international criminal law to ameliorate. Nevertheless, it is no mean feat to spell out how the vehicle of international criminal law could effectively protect against other forms of violence. Indeed, while feminist critiques of international criminal law have succeeded in ensuring women's experiences of sexual violence have been addressed by international criminal tribunals, it has proven a limited and limiting forum for wider feminist-inspired change in relation to the broader economic and patriarchal context within which a trial is rooted. ${ }^{118}$ As Sander observes, 'the political limits of such [criminal] institutions also reflect potentially insurmountable emancipatory limits on what they will ever be able to achieve in practice. By recognizing these limits, greater time, imagination and energy can be directed towards the creation and development of other emancipatory projects.' ${ }^{119}$ In so far as the critical peacebuilding field is interested in law and legal institutions, it can learn from the literature within critical approaches to international criminal law that law too is entrenched in the systemic processes which create and recreate inequality, perhaps even by its very form.

\section{B. Assimilation}

It has been argued that insofar as there are alternative visions of justice or peace within critical approaches to international criminal law or critical peacebuilding projects, these are based on liberal principles. For example, the principles emphasized by critical peace scholars like consent, local ownership, use of traditional practices, participation, empathy and 'solidarity of the governed' are unobjectionable as general principles in liberal peacebuilding theory. Ostensibly different visions of peacebuilding premised on deliberative, constitutional republicanism and post-liberalism are rooted in undeniably liberal values like self-government,

\footnotetext{
116 A.B. Fetherston, 'Peacekeeping, Conflict Resolution and Peacebuilding: A Reconsideration of Theoretical Frameworks', 7 International Peacekeeping (2000) 190, at 207, 208.

${ }^{117}$ Newman, supra note 110, at 1747.

${ }^{118}$ D. Buss, 'Performing Legal Order: Some Feminist Thoughts on International Criminal Law', 11 International Criminal Law Review (2011) 409, at 416.

${ }^{119}$ Sander, supra note 29, at 825.
} 
political participation and limited government. ${ }^{120}$ Ultimately, therefore, it is argued that the critical peacebuilding literature espouses variations within this tradition, as opposed to alternatives to it. ${ }^{121}$ Even the most critical scholars of the liberal peace, like Oliver Richmond, accept the need as part of any sustainable peace for those staples of liberal policy including: the state and its institutions to represent the interests of political subjects; ${ }^{122}$ the "narrow security issues' like disarmament, demobilization and security sector reform; democracy, law and human rights; ${ }^{123}$ and the rationalized, strategic, securitized top-down orthodoxy of politics. ${ }^{124}$ Indeed, some contend that much of the welfarism and poverty alleviation on which critical alternatives to the liberal peace are premised implicitly represents a 'nostalgia' for the liberal social contract - critics are not rejecting intervention, but want to control it via forms of Western social contracting familiar in the Global North in the post Second World War era before the ascendancy of neoliberal economic policy. ${ }^{125}$

This inability to escape the parameters of the object of critique is one that potentially also faces critical approaches to international criminal law. Even if the critique succeeds in making international criminal law more sensitive to its problematic sides or more concerned with everyday lives those societies subjected to interventions than its own institutional selfpreservation, international criminal law will inevitably reproduce some of its own institutional, jurisdictional and philosophical limitations. The extent to which such reproduction then becomes complicity is the treacherous line between reform and revolution, between tactics and strategy. ${ }^{126}$ Sara Kendall offers the example of moving to field-driven rather than Hague-driven investigations which would undoubtedly be a welcome improvement, but concedes it would merely support the type of efficiency critique the critical field aspires to move beyond. ${ }^{127}$ Reflexive critics of international criminal law must remain wary that if the critique of critical approaches to international criminal law makes an impact, international criminal law may succeed in incorporating parts of it in ways that merely deflect criticism without any thoroughgoing reconsideration of the field's biases. ${ }^{128}$

\section{Concluding Remarks}

The disappointment at the empirical records and biases evident in both peacebuilding and international criminal law have increased the relevance of critique that radically disrupts principles and institutions, which were previously taken for granted. Two similar bodies of sophisticated critique about the hegemonic nature of the mainstream peacebuilding and international criminal law projects, their naïve technicism, their potential complicity in repressive domestic politics and their marginalization of socio-economic issues have emerged out of this disappointment. We find that critical approaches to international criminal law has much to learn from both the substance and the trajectory of the liberal peacebuilding critique. The substance of the critique can deepen and enrich critical theory in relation to international

\footnotetext{
${ }^{120}$ R. Paris, 'Saving Liberal Peacebuilding', 36 Review of International Studies (2010) 337, at 354-356.

121 Ibid., at 350, 360.

122 O.P. Richmond, 'Resistance and the Post-Liberal Peace', X Millennium: Journal of International Studies (2010) 665, at 670.

${ }^{123}$ Richmond, supra note 108 , at 563, 572.

${ }^{124}$ O. Richmond, 'Becoming Liberal, Unbecoming Liberalism: Liberal-Local Hybridity Via the Everyday as a Response to the Paradoxes of Liberal Peacebuilding', 3 Journal of Intervention and Statebuilding (2009) 324, at 333.

${ }^{125}$ M. Sabaratnam, 'Avatars of Eurocentrism in the Critique of the Liberal Peace', 44 Security Dialogue (2013) 259 , at 268 .

${ }^{126}$ R. Knox, 'Strategy and Tactics', 21 Finnish Yearbook of International Law (2010) 193.
} 
criminal law, highlighting how parallel interventionist projects can compound the problems. The trajectory of the critique is also instructive. At a certain point, scholars may chafe against the limitations of a critique without or with little impact on policy and face questions whether to engage with the dilemmas of practitioners in the object of study and what such an engagement may look like. From the liberal peacebuilding critique we learn that influence in scholarly discourse is not automatically converted into practice on the ground. Just as critics of liberal peacebuilding appear to stumble from the dangers of assimilation to the pitfalls of irrelevance, this fate may also beset critical projects in international criminal law. The critical peacebuilding literature may, in turn, learn from the critique of critical approaches to international criminal law about the limitations of law and its institutions whilst recognizing the power it wields for tactical radical purposes.

With the more radical critique entering the mainstream, both the mainstream and the critique may reconfigure into a more meaningful, mutually-constituted discourse. This can lead to a greater reflexivity on the part of critical approaches to international criminal law and with that a change in the dialectical relationship between irrelevance and assimilation. Both critical peacebuilding and critical approaches to international criminal law realize their potential most by harassing their respective disciplines when they engage in hubris, by initiating conversations about the revised future practice of their respective apparatuses, by drawing attention to the hidden distributive effects of their practices and relatedly by revealing the moments in which they benefit the powerful at the expense of the weak. And yet, we do not pretend to provide a conclusion which provides a solution. The irrelevance/assimilation dilemma cannot be resolved; instead the recognition of the dilemma can act as a reminder of the necessity for constant self-reflection and navigation. Nevertheless, inasmuch as critique assumes the role of asking the difficult questions, and particularly the ones concerning structures of inequality, to never be content, to eschew the comfort zone of efficiency critiques, it may point the way to a more reflective and legitimate practice. 